\title{
PENGARUH VIRAL MARKETING TERHADAP JUMLAH KUNJUNGAN WISATAWAN INDONESIA KE KOREA SELATAN
}

\author{
Akbar Isawatul Jariah ${ }^{1}$, I GPB. Sasrawan Mananda ${ }^{2}$, I Nyoman Sudiarta ${ }^{3}$ \\ ${ }^{1}$ Email: akbar_isawatul@student.unud.ac.id \\ Program Studi S1 Industri Perjalanan Wisata, Fakultas Pariwisata, Universitas Udayana \\ 2Email: gusmananda@unud.ac.id \\ Program Studi S1 Industri Perjalanan Wisata, Fakultas Pariwisata, Universitas Udayana \\ ${ }^{3}$ Email: sudiarta_ipw@unud.ac.id \\ Program Studi S1 Industri Perjalanan Wisata, Fakultas Pariwisata, Universitas Udayana
}

\begin{abstract}
The aim of this research is to find out how big the influence of viral marketing that has elements of information spreading, credibility of information, expressing positive feelings, economic incentive, and helping the company towards the number of Indonesian tourists visit to South Korea, Sample determination in this study using accidental sampling method with a total of 100 respondents. Data collection techniques used questionnaires, nonparticipation observations, interviews, and literature. Data analysis techniques in this study are descriptive analysis, multiple linear regression analysis, validity and reliability test, hypothesis test, and coefficient of determination analysis using SPSS version 17.0. The results of this study indicate the influence of viral marketing towards the number of Indonesian tourists visit to South Korea is very significantly simultaneous and partial effect with a value of $91,6 \%$. For the economic incentive dimension, the result of analysis is 3,705, helping the company 3,311 , credibility of information 2,461, information spreading 2,220, and expressing positive feelings 2,020. The data collected through online questionnaires to the respondents who have ever visited South Korea
\end{abstract}

\begin{abstract}
Abstrak: Tujuan penelitian ini untuk mengetahui seberapa besar pengaruh viral marketing yang memiliki elemen information spreading, credibility of information, expressing positive feelings, economic incentive, dan helping the company terhadap jumlah kunjungan wisatawan Indonesia ke Korea Selatan. Penentuan sampel dalam penelitian ini menggunakan metode accidental sampling sebanyak 100 responden. Teknik pengumpulan data menggunakan kuesioner, observasi nonpartisipasi, wawancara, dan kepustakaan. Teknik analisis data dalam penelitian ini adalah analisis deskriptif, analisis linier berganda, uji validitas dan reliabilitas, uji hipotesis, dan analisis koefisien determinasi dengan menggunakan SPSS versi 17.0. Hasil dari penelitian ini menunjukkan pengaruh viral marketing terhadap jumlah kunjungan wisatawan Indonesia ke Korea Selatan dinyatakan sangat berpengaruh signifikan secara simultan dan parsial dengan nilai sebesar 91,6\%. Untuk dimensi econimic incentive mendapatkan hasil analisis sebesar 3,705, helping the company sebesar 3,311, credibility of information sebesar 2,461, information spreading sebesar 2,420, dan expressing positive feelings sebesar 2,020. Data penelitian ini diperoleh dari penyebaran kuesioner online kepada responden yang telah berkunjung ke Korea Selatan.
\end{abstract}

Keywords: influence, viral marketing, number of tourists visit. 


\section{PENDAHULUAN}

Dewasa ini aktivitas pariwisata dalam kehidupan masyarakat modern menjadi hal yang telah melekat dalam kehidupan seharihari. Pariwisata adalah kegiatan manusia yang melakukan perjalanan ke dan tinggal di daerah tujuan di luar lingkungan kesehariannya (UNWTO, 1999). Adapun penduduk negara berkembang merupakan penduduk yang paling sering melakukan kegiatan wisata atau bisa dikatakan mengalami peningkatan akhir-akhir ini dan gencar melakukan perjalanan wisata keluar dari negaranya yang disebut dengan outbound tourism. Sektor pariwisata di Indonesia sedang mengalami perkembangan yang cukup besar dapat dilihat dari data kunjungan wisatawan yang berkunjung ke Indonesia pada bulan Desember 2017 naik sebesar 3,03\% dibanding dengan jumlah kunjungan pada bulan Desember 2016 (Badan Pusat Statistik, 2017).

Perkembangan pariwisata di Indonesia juga didukung oleh peningkatan jumlah wisatawan mancanegara yang datang berkunjung ke Indonesia dan juga wisatawan Indonesia yang berwisata ke luar negeri. Indonesia merupakan 10 besar negara yang masuk dalam kategori jumlah wisatawan outbound yang banyak dengan jumlah sebesar 10,6 juta atau $8,6 \%$ untuk negara yang berada di kawasan Asia Pasifik. (Sumber: https://newsroom.mastercard.com). Menurut Manager Potensial Travel Agency Branch Office Garuda Indonesia pada GATF (Garuda Indonesia Travel Fair) April 2018 tujuan favorit wisatawan Indonesia paling banyak di negara-negara Asia Timur seperti Singapura, Haneda (Tokyo), Hong Kong dan Korea Selatan (Sumber: https://inews.id).

Suatu destinasi pariwisata harus mempunyai citra, citra suatu destinasi pariwisata dalah kombinasi antara persepsi konsumen dan usaha menyiapkan produk yang memiliki kelebihan dibandingkan dengan pesaing dan kelebihan dari harapan pelanggan. Membangun citra atau image pada intinya adalah membangun strategi untuk memuaskan konsumen, dan membangun loyalitas konsumen. (Sudiarta, 2012).

Berdasarkan penjelasan mengenai citra suatu destinasi maka dalam penelitian ini yang menjadi salah satu faktor yang membuat wisatawan Indonesia ke luar negeri yaitu adanva faktor nenarik dari destinasi wisata yaitu berupa citra. Atas dasar tersebut mucul lah berbagai cara suatu

destinasi wisata membuat suatu upaya untuk menimbulkan citra positif sehingga menarik wisatawan untuk berkunjung seperti promosi dan penyebaran informasi yang baik.

Lebih lanjut diungkapkan bahwa suatu destinasi wisata merupakan suatu kombinasi dari berbagai elemen yang memberikan pengalaman berbeda dengan tujuan yang sama yaitu memuaskan pengalaman terakhir wisatawan (Sudiarta dan Suardana, 2016). Dalam hal tersebut berbagai macam komponen-komponen yang ada pada suatu destinasi maka wisatawan akan semakin yakin dan percaya dalam melakukan pemilihan terhadap suatu aktivitas wisatanya di daerah yang dituju mereka sebagai destinasi wisata.

Salah satu destinasi wisata yang menjadi pilihan tujuan wisatawan Indonesia yaitu Korea Selatan, menurut KTO (Korea Tourism Organization) yaitu lembaga nonprofit di Korea di bawah perlindungan Departemen Kebudayaan, Olahraga, dan Wisata yang bertujuan untuk mempromosikan industri wisata Korea dengan melakukan kegiatan promosi dan pemasaran. Di Indonesia khususnya Jakarta memiliki kantor KTO sebagai bentuk kerjasama pemerintah Korea Selatan dan Indonesia. KTO menjelaskan kunjungan wisatawan asal Indonesia ke Korea Selatan mengalami peningkatan signifikan dengan tingkat pertumbuhan tertinggi di wilayah Asia Tenggara, yaitu sebanyak 295.461 wisatawan atau naik sebesar 52,62\% dibandingkan dengan tahun 2015 yang berjumlah sebesar 193.590 wisatawan. Walaupun sejak 2010 mengalami fluktuatif namun pada tahun 2016 mengalami peningkatan yang sangat signifikan hal ini dapat dilihat pada Tabel 1 sebagai berikut:

Tabel 1. Jumlah Kunjungan Wisatawan Indonesia ke Korea Selatan 2010-2016

\begin{tabular}{ccc}
\hline Tahun & $\begin{array}{c}\text { Jumlah Wisatawan } \\
(\text { Orang) }\end{array}$ & $\begin{array}{c}\text { Pertumbuhan } \\
(\%)\end{array}$ \\
\hline 2010 & 95.239 & - \\
\hline 2011 & 124.474 & 30,69 \\
\hline 2012 & 149.526 & 20,13 \\
\hline 2013 & 289.289 & 26,53 \\
\hline 2014 & 208.329 & 0,12 \\
\hline 2015 & 193.590 & $-7,07$ \\
\hline 2016 & 295.461 & 52,62 \\
\hline Rata-Rata & 179.401 & 17,55 \\
\hline
\end{tabular}


Hubungan serta pertukaran warga antara negara Indonesia dengan Korea Selatan dalam berbagai bidang semakin meningkat sejak terjalinnya hubungan diplomatik secara resmi antar kedua negara sejak tahun 1966 (Syarief, 2016). Kerjasama antar Indonesia dan Korea Selatan yang menjadi prioritas yaitu dari bidang ekonomi, dan sosial budaya. Korea Selatan merupakan salah satu negara di Asia dengan nilai ekonomi trilliyunan dollar, sehingga membuat Korea Selatan menjadi pusat perharian dunia (Herliani, 2017).

Muncul suatu fenomena yang sangat menarik pada pertengahan tahun 1999 dan diungkapkan oleh jurnalis asal yaitu Hallyu. Istilah "Hallyu" pertama kali muncul dari media Cina ketika dia heran melihat semakin banyaknya barang-barang produksi asal Korea Selatan masuk ke Cina. Mereka kemudian menyebut fenomena baru ini sebagai "Hanliu" (韩流). Hallyu berasal dari 2 kata: Han ( $\square$ ) mengacu pada kualitas atau keadaan Korea sementara, dan Ryu ( $\square$ ) berarti mengalir. Sehingga digabung menjadi satu kata majemuk " $\square \square$ " (han-ryu) dibaca "hallyu", yang secara harfiah berarti "aliran Korea" (Kim Bok-Rae, 2015).

Hallyu meliputi budaya tradisional Korea Selatan yang dipadupadankan dengan budaya pop kemudian disajikan ke dalam berbagai macam bentuk seperti K-Pop, K-Drama, $K$ Movie, K-Style, K-Food, K-Place, K-Spirit, dan $K$-Wave. Budaya $K$-Pop telah mulai menyebar luas tidak hanya dikawasan Asia tapi juga menyebar ke kawasan Timur Tengah, Afrika, Eropa dan Amerika Serikat (Sue Jin Lee, 2011).

Dikemukakan oleh KTO (Korea Tourism Organization) yang berada di Jakarta pada bulan September 2017 bahwa jumlah wisatawan Indonesia yang melakukan perjalanan wisata ke Korea Selatan terus meningkat setiap tahunnya di tengah popularitas Hallyu. Kepopuleran Hallyu bagi Korea Selatan merupakan suatu citra positif yang dikenalkan kepada wisatawan yang berkunjung ke Korea Selatan karena hal tersebut yang menjadi suatu media promosi yang membrikan dampak yang positif dan sangat baik bagi wisatawan yang berkunjung di Korea Selatan.

Berkembangnya Hallyu di Indonesia memberikan dampak terhadap masyarakat di

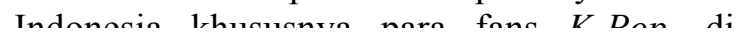

Indonesia secara tidak langsung mempengaruhi minat masyarakat untuk berwisata ke Korea Selatan, selain itu juga banyak masyarakat Indonesia yang ingin mempelajari bahasa serta budaya termasuk makanan dan fashion (Pramita dan Harto, 2016).

Seiring dengan perkembangan teknolgi serta penggunaan media internet wisatawan saat ini cenderung sering untuk melakukan pencarian informasi terkait destinasi serta objek wisata yang akan dikunjunginya dengan media internet. Promosi merupakan salah satu program komunikasi yang dianggap penting dan efektif bagi perusahaan, dan media promosi yang paling sering digunakan akhirakhir ini adalah media sosial. Penggunaan media sosial tentunya bukan hanya digunakan oleh pribadi namun sekarang banyak perusahaan, organisasi, serta seluruh aspek lainnya turut menggunakan media sosial.

Pemerintah Korea Selatan tidak berhenti pada kegiatan fenomena Hallyu saja, justru mengambil kesempatan yang terbuka yaitu dalam mengembangkan pariwisatanya dengan memadukan fenomena Hallyu dengan promosi tagline pariwisata mereka yaitu Imagine Your Korea. Akun media sosial yang digunakan oleh KTO (Korea Tourism Organization) dalam mempromosikan Imagine Your Korea adalah Youtube, Facebook, Instagram, dan Twitter. Akun tersebut dibuat sejak tahun 2011, untuk tahun 2017 Korea Selatan mengusung Lee Jong Suk sebagai duta pariwisata negaranya atau diistilahkan dengan 2017 Korea Tourism Honorary Ambassador.

Di sisi lain dikemukakan oleh We Are Social, sebuah agensi pemasaran sosial melaporkan bahwa penggunaan aktif internet di Indonesia sebanyak 132,7 juta pengguna yang di mana mengalami pertumbuhan sejak Januari 2016 sebesar 51\% dan untuk pengguna media sosial berjumlah 106 juta pengguna yng menglami perkembangan jika dibandingkan Januari 2016 sebesar 34\% (Sumber: www.wearesocial.com).

Media yang paling efektif dalam melakukan promosi baik itu barang maupun jasa yaitu media sosial. Pada jejaring media sosial ada berbentuk pesan, gambar, maupun video, bentuk pesan yang terdapat pada media sosial tersebut yang ditayangkan secara terus menerus yang disebut sebagai viral marketing (nemasaran viral) Rerdasarkan lanoran We 
media sosial di Indonesia yang paling banyak digunakan pada tahun 2017 yaitu jejaring media sosial Youtube, Facebook, Instagram, dan Twitter (Sumber: www.wearesocial.com Most Active Social Media Platforms Indonesia 2017). Korea Selatan juga menggunakan keempat media sosial tersebut sebagai alat untuk memasarkan Imagine Your Korea.

Berangkat dari berbagai fenomena yang ada seperti peningkatan yang signifikan jumlah kunjungan wisatawan Indonesia ke Korea Selatan, pemanfaatan pemasaran melalui media sosial, dan menjamurnya fenomena Hallyu di Indonesia, maka perlu adanya penelitian mengenai bagaimana pengaruh viral marketing terhadap jumlah kunjungan wisatawan Indonesia ke Korea Selatan dan dimensi viral marketing yang mana yang paling berpengaruh terhadap jumlah kunjungan wisatawan Indonesia ke Korea Selatan.

\section{METODE}

Dalam penelitian ini menggunakan lima dimensi yang telah dielaborasi dari dimensidimensi pada jurnal Khalid Alkharabshes dan Mohammad Nayef Sarayreh (2011) dan jurnal Ali Hasan dan Niken Widiati Setyaningtiyas (2015). Lima dimensi tersebut sebagai variabel bebas viral marketing yang digunakan dalam penelitian ini yaitu: (1) information spreading, (2) credibility of information, (3) expressing positive feelings, (4) economic incentive, serta (5) helping the company.

Pada variabel jumlah kunjungan wisatawan Indonesia ke Korea Selatan dikaitkan dengan penelitian Zakaria (2015) mengenai perilaku pasca berkunjung dengan modifikasi yaitu: (1) Ketertarikan memilih destinasi, (2) Ketepatan informasi, (3) Rencana untuk berkunjung kembali, serta (4) Kepuasan memilih destinasi.

Teknik pengumpulan data yang digunakan yaitu penyebaran kuesioner, observasi nonpartisipasi, wawancara, dan kepustakaan. Teknik penentuan informan ditentukan secara purposive sampling kepada orang-orang yang dipandang tahu tentang situasi sosial tersebut. Penentuan sampel dilakukan dengan accidental sampling, siapa saja yang secara kebetulan dapat dijadikan sebagai sampel dan cocok sebagai sumber data (Sugiyono, 2014). Jumlah responden yang diounakan adalah sehanvak 100 resnonden
Indonesia yang telah berkunjung ke Korea Selatan untuk melakukan perjalanan wisata. Teknik analisis data menggunakan analisis deskriptif, analisis linier berganda, uji validitas dan reliabilitas, uji hipotesis, dan analisis keofisien determinasi.

\section{HASIL}

\section{Karakteristik Wisatawan Indonesia yang Berkunjung ke Korea Selatan}

Dari 100 responden dalam penelitian ini merupakan warga negara Indonesia yang telah berkunjung ke Korea Selatan. Karakteristik responden berdasarkan kota asalnya menunjukkan bahwa 100 responden yang mengisi kuesioner merupakan wisatawan yang berasal dari 10 kota yang berbeda-beda dengan nilai persentase terbesar diperoleh oleh wisatawan yang berasal dari Sulawesi Selatan sebesar 46\%. Berdasarkan jenis kelamin jumlah terbanyak berasal dari wisatawan yang berjenis kelamin Perempuan sebesar 70\%. Kemudian karakteristik wisatawan menurut usia yaitu pada rentang umur $21 \mathrm{~s} / \mathrm{d} 30$ tahun yang mendominasi sebesar 50\%. Berdasarkan status paling banyak wisatawan yang berkunjung mempunyai status belum menikah yaitu sebesar $67 \%$.

Karakteristik lainnya yang berpengaruh yaitu berdasarkan pendidikan terakhir yaitu SMA sebesar $40 \%$. Selanjutnya karakteristik wisatawan berdasarkan pekerjaan yaitu Pelajar/Mahasiswa dengan persentase sebesar $53 \%$. Dapat dilihat lagi karakteristik wisatawan yaitu pada penghasilan perbulan yaitu kurang dari Rp. 2.000 .000 sebesar $41 \%$. Sebanyak 100 responden paling sering menggunakan media sosial Instagram sebesar $65 \%$ dan frekuensi penggunaannya pada rentang $4 \mathrm{~s} / \mathrm{d} 6$ Jam perhari dengan nilai sebesar 36\%.

Karakteristik lainnya yang berpengaruh terhadap jumlah kunjungan wisatawan Indonesia ke Korea Selatan yaitu 68\% mengetahui mengenai Imagine Your Korea. Waktu berkunjung yang paling disukai oleh wisatawan Indonesia yaitu pada musim salju (Desember - Februari) dengan persentase sebesar 46\%. Karakteristik lainnya yaitu menurut pesawat yang digunakan didominasi oleh wisatawan yang menggunakan maskapai Garuda Indonesia sebesar 38\%. Berdasarkan teman perjalanan ketika mengunjungi Korea Selatan mereka heneroian hersama keluaroa 
berkunjung di Korea Selatan $>5$ hari sebesar $66 \%$. Karakteristik wisatawan menurut ketertarikan mengunjungi Korea Selatan yaitu memilih budaya dengan jumlah 64 orang yang memilih budaya dari 100 responden.

\section{Hasil Analisis Data}

Berdasarkan hasil analisis deskriptif variabel viral marketing secara keseluruhan berpengaruh terhadap jumlah kunjungan wisatawan dengan besaran skor rata-rata sebesar 416. Uji validitas dalam penelitian ini dapat dinyatakan bahwa semua indikator yang digunakan telah diuji dan valid karena telah melebihi syarat koefisien korelasi lebih besar dari 0,3. Instrumen tertinggi dalam penelitian yang diuji yaitu sub variabel expressing positive feelings (X3.1) dengan koefisien korelasi sebesar 0,940 atau indikator melalui media sosial saya dapat merasakan kesenangan orang lain saat ataupun setelah mengunjungi Korea Selatan.

Hasil uji reliabilitas menghasilkan nilai cronbach's alpha sebesar 0,955. Nilai cronbach's alpha tersebut lebih besar dari 0,6 yang berarti koefisien reliabilitas $=0,955>0,6$ sehingga instrumen dinyatakan reliabel. Berdasarkan hasil analisis regresi berganda antara variabel independen independen (X1, X2, X3, X4, X5) atau (information spreading, credibility of information, expressing positive feelings, economic incentive, dan helping the company) dengan variabel dependen (Y) atau jumlah kunjungan wisatawan Indonesia ke Korea Selatan dapat diperoleh persamaan regresi berganda sebagai berikut:

$\mathrm{Y}=\mathrm{a}+\mathrm{b} 1 \mathrm{X} 1+\mathrm{b} 2 \mathrm{X} 2+\mathrm{b} 3 \mathrm{X} 3+\mathrm{b} 4 \mathrm{X} 4+\mathrm{b} 5 \mathrm{X} 5+\mathrm{e}$

Sehingga persamaan regresi berganda dalam penelitian ini yaitu :

$$
\begin{aligned}
\mathrm{Y}= & 0,195+0,247+0,168+0,307+0,413+ \\
& 0,432
\end{aligned}
$$

Dimana:

$\mathrm{Y}=$ Jumlah Kunjungan Wisatawan

$\mathrm{a}=$ Konstanta

$\mathrm{X} 1$ = Information Spreading

$\mathrm{X} 2=$ Credibility of Information

$\mathrm{X} 3=$ Expressing Positive Feelings

$\mathrm{X} 4=$ Economic Incentive

$\mathrm{X} 5$ = Helping the Company

Untuk pengujian hipotesis dalam penlitian ini menggunakan dua cara yatiu dengan uji secara parsial (Uji t) dan uji secara simultan (Uii F). Berikut hasil penguiian hipotesis dengan nilai t-hitung dan nilai signifikansi sebagai berikut:

\section{Hasil Uji Signifikan Regresi Berganda Secara Parsial (Uji t)}

Jika nilai hitung positif dengan taraf signifikansi $(0,001)<\alpha(0,05)$ maka variabel information spreading, credibility of information, expressing positive feelings, economic incentive, dan helping the company berpengaruh positif dan signifikan terhadap variabel Jumlah Kunjungan Wisatawan Indonesia ke Korea Selatan. Jika nilai t hitung dengan taraf signifikansi $(0,001)>\alpha(0,05)$ maka variabel information spreading, credibility of information, expressing positive feelings, economic incentive, dan helping the company tidak berpengaruh positif dan signifikan terhadap variabel Jumlah Kunjungan Wisatawan Indonesia ke Korea Selatan.

\section{Information Spreading (X1) Terhadap Jumlah Kunjungan Wisatawan Indonesia ke Korea Selatan (Y)}

Berdasarkan hasil t-hitung, variabel X1 information spreading yang terdiri dari 3 indikator adalah sebesar 2,420 dan bernilai positif dengan tingkat signifikansi sebesar 0,018 . Karena nilai t hitung positif dan nilai signifikansinya $0,018<0,05$ dapat disimpulkan bahwa variabel information spreading berpengaruh positif dan signifikan terhadap jumlah kunjungan wisatawan Indonesia ke Korea Selatan.

\section{Credibility of Information (X2) Terhadap Jumlah Kunjungan Wisatawan Indonesia ke Korea Selatan (Y)}

Berdasarkan hasil t hitung, variabel X2 credibility of information yang terdiri dari 4 indikator adalah sebesar 2,461 dan bernilai positif dengan tingkat signifikansi sebesar 0,016 . Karena nilai $t$ hitung positif dan nilai signifikansinya $0,016<0,05$ dapat disimpulkan bahwa variabel credibility of information berpengaruh positif dan signifikan terhadap jumlah kunjungan wisatawan Indonesia ke Korea Selatan.

Expressing Positive Feelings (X3) Terhadap Jumlah Kunjungan Wisatawan Indonesia ke Korea Selatan (Y)

Rerdasarkan hasil t hitıno variahel X3 
indikator adalah sebesar 2,020 dan bernilai positif dengan tingkat signifikansi sebesar 0,047 . Karena nilai t hitung positif dan nilai signifikansinya $0,047<0,05$ dapat disimpulkan bahwa variabel expressing positive feelings berpengaruh positif dan signifikan terhadap jumlah kunjungan wisatawan Indonesia ke Korea Selatan.

\section{Economic Incentive (X4) Terhadap Jumlah} Kunjungan Wisatawan Indonesia ke Korea Selatan (Y)

Berdasarkan hasil t hitung, variabel X4 economic incentive yang terdiri dari 3 indikator adalah sebesar 3,705 dan bernilai positif dengan tingkat signifikansi sebesar 0,000 . Karena nilai $\mathrm{t}$ hitung positif dan nilai signifikansinya $0,000<0,05$ dapat disimpulkan bahwa variabel economic incentive berpengaruh positif dan signifikan terhadap jumlah kunjungan wisatawan Indonesia ke Korea Selatan.

\section{Helping the Company (X5) Terhadap Jumlah Kunjungan Wisatawan Indonesia ke Korea Selatan (Y)}

Berdasarkan hasil t hitung, variabel X5 helping the company yang terdiri dari 2 indikator adalah sebesar 3,311 dan bernilai positif dengan tingkat signifikansi sebesar 0,001 .

Karena nilai t hitung positif dan nilai signifikansinya $0,001<0,05$ dapat disimpulkan bahwa variabel helping the company berpengaruh positif dan signifikan terhadap jumlah kunjungan wisatawan Indonesia ke Korea Selatan.

Dari hasil uji signifikan regresi berganda secara parsial (t-test) dapat diketahui iika variabel bebas Information spreading (X1), credibility of information (X2), expressing positive feelings (X3), economic incentive (X4), dan helping the company (X5) terbukti berpengaruh positif dan signifikan terhadap terhadap variabel terikat yaitu Jumlah Kunjungan Wisatawan Indonesia ke Korea Selatan (Y) sehingga hipotesis dalam penelitian ini terjawab dan terbukti.

\section{Hasil Uji Signifkan Regresi Berganda Secara Simultan (Uji F)}

Hasil pengujian uji $F$ menunjukkan bahwa nilai sig. untuk pengaruh variabel $\mathrm{X}$ secara simultan terhadan $\mathrm{Y}$ adalah sehesar disimpulkan bahwa dari hasil uji signifkan regresi berganda secara bebas (f-test) maka keseluruhan variabel bebas yaitu information spreading (X1), credibility of information (X2), expressing positive feelings (X3), economic incentive (X4), dan helping the company (X5) secara simultan berpengaruh positif dan signifikan terhadap variabel terikat yaitu Jumlah Kunjungan Wisatawan Indonesia ke Korea Selatan (Y).

\section{Koefisien Determinasi}

Berdasarkan hasil koefisien determinasi dapat dijelaskan bahwa koefisien determinasi memiliki nilai $\mathrm{R}$ Square $(0,957)$ sehingga koefisien determinasi dalam penelitian ini sebesar 91,6\% dan memberikan hasil bahwa variabel bebas yang terdiri dari information spreading (X1), credibility of information (X2), expressing positive feelings (X3), economic incentive (X4), dan helping the company (X5) terhadap variabel terikat yaitu Jumlah Kunjungan Wisatawan Indonesia ke Korea Selatan $91,6 \%$ sementara sisanya yaitu $100 \%-91,6 \%=8,4 \%$ dipengaruhi oleh variabel-variabel lain seperti teori-teori viral marketing lainnya yang dikembangkan pada penelitian lain yang tidak diteliti lebih lanjut dalam penelitian ini.

\section{PEMBAHASAN}

\section{Pengaruh Viral Marketing Terhadap Jumlah Kunjungan Wisatawan Indonesia ke Korea Selatan}

Pengukuran pengaruh suatu aktivitas pemasaran melalui media sosial yang dilakukan oleh pihak Korea Selatan dalam mendatangkan wisatawan berkunjung ke negaranya khususnya wisatawan yang berasal dari negara Indonesia yaitu dengan menggunakan viral marketing yang memiliki sub variabel Information spreading (X1), credibility of information (X2), expressing positive feelings (X3), economic incentive (X4), dan helping the company (X5) telah terbukti berpengaruh terhadap Jumlah kunjungan wisatawan Indonesia ke Korea Selatan (Y). Dimensi-dimensi tersebut terwakili oleh 18 pernyataan yang diajukan kepada 100 responden dalam kuesioner. Indikator dari information spreading (X1) dalam penelitian ini terdiri atas; (1) keterlibatan dengan informasi, (2) fleksibilitas media informasi (3) kemudahan dan ketenatan 
Untuk indikator sub variabel kedua credibility of information (X2) dalam penelitian ini terdiri atas; (1) kepercayaan terhadap informasi, (2) kelengkapan informasi, (3) sumber informasi terpercaya, dan (4) media interaktif. Selanjutnya indikator sub variabel ketiga yaitu expressing positive feelings (X3) dalam penelitian ini terdiri atas (1) menimbulkan perasaan positif dan (2) membahas pengalaman positif. Sub indikator keempat yaitu economic incentive (X4) dalam penelitian ini terdiri atas; (1) efisiensi waktu, (2) efisiensi biaya, dan (3) kemudahan. Sub indikator terakhir yaitu helping the company (X5) dalam penelitian ini terdiri atas; (1) kesediaan membantu dan (2) kesediaan merekomendasikan.

Pada hasil analisis pengujian validitas dan reliabilitas, dapat diketahui dari 18 indikator dimana 14 indikator dalam variabel viral marketing dan 4 indikator dalam jumlah kunjungan wisatawan Indonesia ke Korea Selatan dinyatakan valid dan reliabel karena koefisien korelasi dan cronbach's alpha telah memenuhi syarat pengujian, dimana melebihi 0,30 untuk pengujian validitas dan 0,60 untuk pengujian reliabilitas. Setelah dilakukan pengujian validitas dan reliabilitas dilakukan pengujian analisis regresi linier berganda.

Pada hasil analisis regresi berganda yang telah dilakukan secara parsial kelima variabel independen telah terbukti berpengaruh positif dan signifikan terhadap variabel dependen, karena telah memenuhi syarat penerimaan hipotesis, yaitu nilai sig. lebih kecil dari 0,050 sehingga hipotesis dalam penelitian ini telah terbukti.

Secara simultan, lima variabel indpenden terbukti berpengaruh terhadap variabel dependen, karena nilai sig. lebih kecil dari 0,050 sehingga telah memenuhi syarat penerimaan hipotesis. Dari hasil analisis determinasi dimana untuk mengetahui sejauh mana pengaruh variabel independen terhadap variabel dependen, diketahui jika pengaruh viral marketing terhadap jumlah kunjungan wisatawan Indonesia ke Korea Selatan adalah $91,6 \%$ dan sisanya $8,4 \%$ dipengaruhi oleh faktor-faktor pendorong dan penarik lainnya dan variabel-variabel viral marketing lainnya seperti increase competitiveness, concern for others, platform assistance yang tidak diteliti lebih lanjut dalam penelitian ini. Hal tersebut menuniukkan hahwa variahel viral markotino variabel jumlah berkunjung wisatawan Indonesia ke Korea Selatan.

Adapun hasil penelitian yang dilakukan yang didapatkan berdasarkan uji $\mathrm{F}$ yaitu sebesar 171.358 dengan tingkat probabilitas $0,000<0,050$ sehingga variabel viral marketing berpengaruh secara signifikan terhadap jumlah kunjungan wisatawan Indonesia ke Korea Selatan ketika adanya viral marketing yang disebarkan oleh pemerintah Korea Selatan dan disertakan dengan adanya promosi yang dibuat oleh pemerintah Korea Selatan dengan viral marketing.

Penelitian ini juga sejalan dengan penelitian sebelumnya yang dilakukan oleh Alkharabsheh dan Sarayreh (2011), variabel yang digunakan dalam penelitian ini adalah Promotion of Tourism Products sebagai variabel dependen sedangkan variabel independen yang digunakan adalah viral marketing. Berdasarkan hasil penelitiannya menunjukkan bahwa variabel viral marketing berpengaruh signifikan secara simultan dan parsial terhadap Promotion of Tourism Products in Jordan. Penelitian ini juga sejalan dengan penelitian sebelumnya yang dilakukan oleh Hasan dan Setyaningtiyas (2015) variabel yang digunakan dalam penelitian ini adalah keputusan berkunjung sebagai variabel dependen sedangkan variabel independen yang digunakan adalah electronic word of mouth. Berdasarkan hasil penelitiannya menunjukkan bahwa tiga variabel electronic word of mouth tersebut berpengaruh signifikan secara parsial terhadap keputusan berkunjung wisatawan ke Desa Wisata Ngalanggeran Gunung Kidul.

Penelitian ini sejalan dengan elaborasi penelitian Alkharabsheh dan Sarayreh (2011) dan juga penelitian Hasan dan Setyaningtiyas (2015) dengan mengambil lima dimensi diantara penelitian mereka yaitu information spreading, credibility of information, expressing positive feelings, economic incentive, dan helping the company. Kelima dimensi ini memberikan pengaruh yang signifikan secara simultan dan parsial terhadap jumlah kunjungan wisatawan Indonesia ke Korea Selatan dalam penelitian ini.

\section{Dimensi Viral Marketing yang Paling Berpengaruh Terhadap Jumlah Kunjungan Wisatawan Indonesia ke Korea Selatan}

Hasil analisic nii $t$ nada analisis reoresi 
pengaruh tiap sub variabel viral marketing sebagai berikut:

\section{$\mathrm{X} 1$ Information Spreading $=2,420$ \\ $\mathrm{X} 2$ Credibility of Information $=2,461$ \\ $\mathrm{X} 3$ Expressing Positive Feelings $=2,020$ \\ $\mathrm{X} 4$ Economic Incentive $=3,705$ \\ $\mathrm{X} 5$ Helping the Company $=3,311$}

Berdasarkan hasil analisis uji $t$ menunjukkan variabel economic incentive (X4) lebih besar pengaruhnya terhadap jumlah kunjungan wisatawan Indonesia ke Korea Selatan dibandingkan dengan variabel viral marketing lainnya dengan besaran pengaruh 3,705 kemudian diikuti dengan dimensi helping the company sebesar 3,311 selanjutnya dimensi credibility of information sebesar 2,461 kemudian dimensi information spreading sebesar 2,420 dan yang paling rendah besaran pengaruhnya adalah expressing positive feelings dengan ini 2,020.

Hal ini berarti economic incentive atau insentif ekonomi yang diberikan oleh pemerintah Korea Selatan seperti penyediaan penyebaran promosi pariwisata Korea Selatan disediakan dalam bentuk media sosial yang dengan mudah diakses oleh wisatawan yang akan, sedang, maupun telah berkunjung ke Korea Selatan. Promosi pariwisata yang dilakukan KTO (Korea Tourism Organization) diberikan secara cuma-cuma melalui media sosial kepada wisatawan sehingga memberikan kemudahan serta efisiensi biaya maupun waktu kepada wisatawan dalam mengakses serta membahas promosi pariwisata Korea Selatan dengan wisatawan lainnya.

Berdasarkan hasil yang ditemukan ternyata hasil penelitian ini menunjukkan dimensi viral marketing yang paling berpengaruh adalah economic incentive berbeda dengan penelitian-penelitian sebelumnya yang menyatakan bahwa penggunaan viral marketing yang paling berpengaruh adalah dimensi information spreading.

\section{SIMPULAN DAN SARAN Simpulan}

Berdasarkan hasil penelitian yang telah dilakukan mengenai pengaruh viral marketing terhadap jumlah kunjungan wisatawan Indonesia ke Korea Selatan maka danat pengaruh secara parsial dan simultan terhadap jumlah kunjungan wisatawan Indonesia ke Korea Selatan. Dari hasil analisis determinasi pengaruh viral marketing terhadap jumlah kunjungan wisatawan Indonesia ke Korea Selatan diperoleh nilai 91,6\%. Hal ini menunjukkan bahwa viral marketing sebesar $91,6 \%$ sangat berpengaruh terhadap jumlah kunjungan wisatawan Indonesia ke Korea Selatan. Sedangkan sisanya $8,4 \%$ dipengaruhi oleh faktor lain yang tidak diteliti lebih lanjut pada penelitian ini.

Berdasarkan dimensi viral marketing yang paling berpengaruh terhadap jumlah kunjungan wisatawan Indonesia ke Korea Selatan adalah economic incentive dengan hasil analisis sebesar 3,705, kemudian diikuti oleh helping the company sebesar 3,311, lalu credibility of information sebesar 2,461, dan information spreading sebesar 2,420, dan yang terakhir yaitu expressing positive feelings sebesar 2,020.

\section{Saran}

Berdasarkan hasil dari penelitian maka serta pembahasan maka dapat dikemukakan saran yatitu viral marketing yang diberikan oleh Pemerintah Korea Selatan pada jumlah kunjungan wisatawan Indonesia ke Korea Selatan sudah sangat baik namun harus ada pembenahan yang dilakukan terhadap indikator Expressing Positive Feelings, hal ini ditunjukkan pada indikator-indikatornya pada hasil kuesioner yang memiliki nilai paling rendah dibandingkan dengan indikator lainnya. Maka dari itu diperlukan penanganan yang lebih baik terhadap viral marketing agar dapat menambah jumlah kunjungan wisatawan Indonesia ke Korea Selatan.

Perlu ditingkatkan lagi inovasi-inovasi baru dan konten-konten promosi baru yang lebih inovatif setiap tahunnya agar terkesan tidak mononton dalam menarik kunjungan wisatawan negara lain melalui viral marketing berupa pemasaran video Imagine Your Korea melalui keempat media sosial yang digunakan yaitu Youtube, Facebook, Instagram, dan Twitter terhadap jumlah kunjungan wisatawan ke Korea Selatan secara berkelanjutan dan berkala.

Untuk pemerintah Indonesia khususnya dalam mengembangkan pariwisata dapat mengikuti cara yang dilakukan oleh Korea Selatan menoinoat haousnva cara nenoemasan 
Selatan. Sebagai contoh video Wonderful Indonesia bisa dikemas lebih baik lagi dan lebih bervariasi lagi seperti yang dilakukan Korea Selatan pada video Imagine Your Korea. Promosi pariwisata yang dilakukan oleh KTO (Korea Tourism Organization) setiap tahunnya memberikan tema dan cara promosi yang berbeeda-beda melalui keempat media sosial utama yang digunakan yaitu Youtube, Facebook, Instagram, dan Twitter sebagai contoh tahun 2017 menyediakan delapan jenis video yang berbeda dan diadakan kuis yaitu memilih video yang menjadi favorit wisatawan dan berkesempatan mendapatkan hadiah seperti tiket pulang pergi gratis ke Korea Selatan. Promosi yang dilakukan juga mengusung Korea Tourism Honorary Ambassador berupa aktor ataupun penyanyi Korea Selatan yang setiap tahunnya berbeda-beda yang dipilih berdasarkan drama atau lagu yang dibawakan memiliki tingkat popularitas yang tinggi pada tahun sebelumnya. Pemerintah Indonesia juga disarankan untuk mengoptimalkan penggunaan sosial media dalam mempromosikan pariwisata di Indonesia kepada wisatawan mancanegara dilihat dari segi tren wisata saat ini yang dimana wisatawan cenderung lebih memilih mengakses informasi pariwisata suatu negara dengan mengakses internet khususnya media sosial seperti yang diterapkan oleh Korea Selatan. 


\section{Kepustakaan}

Alkharabsheh, K. dan Sarayreh, M.N. (2011). The Impact of Viral Marketing Via Internet on Promotion of Tourism Products in Jordan. International Research Journal of Finance and Economics-Issue 80.

Badan Pusat Statistik, 2017, Jumlah Kunjungan Wisatawan Ke Indonesia 2017, Diakses pada Desember 2017, dari https://www.bps.go.id/pressrelease/2017/12/0 1/1468/jumlah-kunjungan-wisman-keindonesia-desember-2017-mencapai-1-15-juta

Hasan, A. dan Setyaningtiyas, N.W. (2015). Pengaruh Electronic Word of Mouth Pada Media Sosial Facebook Terhadap Keputusan Berkunjung Ke Desa Wisata Nglanggeran Gunungkidul. Jurnal Media Wisata, Volume 13, No. 1, 224-238.

Herliani, Putri. 2017. Pengaruh Korean Wave Terhadap Animo Masyarakat Indonesia Untuk Berwisata Ke Korea Selatan. Bandung: Universitas Pasundan.

Inews Finance, 2018, Ini Tujuan Penerbangan Favorit Pengunjung Selama GATF 2018, Diakses Pada Maret 2018, dari http://www.inews.id/finance/read/ini-tujuanpenerbangan-favorit-pengunjung-selama-gatf2018

Kim, B.R. (2015). Past, Present, and Future of Hallyu (Korean Wave). American International Journal of Contemporary Research, Volume 5, No. 5, 154-160.

Korea Tourism Organization, 2017, Jumlah Kunjungan Wisatawan Indonesia ke Korea Selatan, Diakses Pada Desember 2017, dari https://english.visitkorea.or.kr/enu/index.kto

Lee, S.J. (2011). The Korean Wave: The Soul of Asia. The Elon Journal of Undergraduate Research in Communications, Volume 2, No. 1, 85-93.

Mastercard, 2017, Report - Mastercard Future of Outbound Travel in Asia Pasific (2016 to 2021), Diakses Pada Desember 2017, dari https://newsroom.mastercard.com/asiapasific/documents/the-future-of-outboundtravel-in-asia-pasific-2016-to-2021/

Pramita, Y. dan Harto, S. (2016). Pengaruh Hallyu Terhadap Minat Masyarakat Indonesia Untuk Berwisata Ke Korea Selatan. JOM FISIP, Vol. 3, No. 2, 1-15.

Sudiarta, I.N. (2012). Membangun Citra (Destinasi) Pariwisata Seberapa Pentingkah?. Jurnal Ekonomi dan Pariwisata, Vol. 7, No. 31, 6075.

Sudiarta, I.N. dan Suardana, I.W. (2016). Tourism Destination Planning Strategy: analysis and implementation of marketing city tour in Bali. Procedia - Social and Behavioral Sciences
Sugiyono. 2014. Metode Penelitian Kauntitatif dan Kualitatif dan $R \& D$. Bandung: Alfabeta.

Syarief, Muh Nizar. 2016. Kerjasama Indonesia Korea Selatan Di Bidang Manufaktur. Makassar: Universitas Hasanuddin.

UNWTO, 1999, Pengertian Pariwisata, Diakses Pada Februari 2018, dari http://www2.unwto.org/

We Are Social, 2017, The Most Active Social Media Platforms, Diakses Pada Desember 2017, dari https://wearesocial.com/uk/

Zakaria, Gitta Parlina. 2015. Pengaruh Museum Experience Terhadap Perilaku Pasca Berkunjung. Bandung: Universitas Pendidikan Indonesia. 